\title{
Awareness and Attitude Towards Green IS in Slovenian Enterprises
}

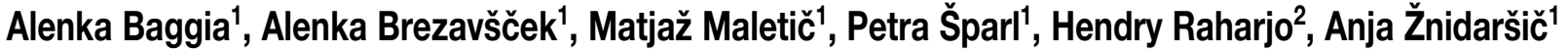

\author{
${ }^{1}$ University of Maribor, Faculty of Organizational Sciences, Kidričeva cesta 55a, 4000 Kranj, Slovenia \\ alenka.baggia@fov.uni-mb.si \\ ${ }^{2}$ Chalmers University of Technology, Department of Technology Management and Economics, SE-412 96 \\ Gothenburg, Sweden, hendry.raharjo@chalmers.se
}

Background: This study draws upon the use of Information Systems in support of achieving sustainability, known as Green IS. Furthermore, this study builds on the premise that Green IS offers the opportunity for organizations to act proactively in terms of environmental preservation as well as to mitigate the effects of global climate change and other environmental problems.

Aim: In particular, this study aims to assess the extent of awareness among managers regarding the use and the acceptance of Green IS in Slovenian enterprises.

Method: Using empirical data based on a large-scale survey among senior managers within Slovenian enterprises this study utilized several statistical methods (such as t-test, analysis of variance and multiple linear regression) to analyse the research questions.

Results: In general, findings seem to suggest that institutional mechanisms might be a plausible explanation for differences regarding the attitude towards Green IS adoption. For instance, enterprises with at least one implemented sustainability related certificate expressed higher levels of willingness to use Green IS in order to facilitate the achievement of sustainable development. Moreover, the results of the regression analysis revealed that both Institutional Mimetic pressure and Internal Environment Impact has positive impact on Green IS adoption.

Conclusion: The main conclusion is that the internal environmental impact is considered the most influential factor of the attitude towards Green IS adoption. The culture or individual perception of managers and employees play an important role in the Green IS adoption. Indeed, enterprises that have no intention of improving their environmental performance, but adopt Green IS by the means of seeking legitimacy among external stakeholders, cannot provide a sustainable improvement in environmental management.

Keywords: Green Information System, Sustainability, Environment, Information System

\section{Introduction}

Global warming and other environmental threats have lately increased the level of environmental awareness (Dedrick, 2010). Individuals, organizations and governments are becoming aware of the necessity of sustainability for performing and managing work (Siedel, Recker, Pimmer $\&$ vom Brocke, 2010). Since information technologies and information systems represent $2 \%$ of $\mathrm{CO} 2$ emissions (WWF, Gartner Group, 2008) and this share is supposed to increase to 3\% until 2020 (McKinsey Global Institute, 2008), the shift towards green or sustainable economy seems inevitable. Environmental issues have forced the information technologies and consequently information systems to become more environmentally friendly, enabling energy efficient business processes (Brooks, Wang \& Sarker, 2012). It is also evident, that business process management (Siedel et al., 2011) and the shift towards the sustainable business practices can benefit substantially from Green information systems (Green IS) practices with Green

Received: $19^{\text {th }}$ September, 2015; revised: $7^{\text {th }}$ November 2015; accepted; $6^{\text {th }}$ January 2016 
information technology (Green IT) as an enabler (Esfahani, Rahman and Zakaria, 2015).

Watson, Boudreau, Chen and Huber (2008) were the first to carefully distinguish between Green IS and Green IT. The concept of Green IS can be defined as the usage of information systems to enable sustainable development in economy (Boudreau, Chen \& Huber, 2007; Watson et al., 2008). Green IS are enabled by a unique structure of people, processes and IT with a goal to achieve eco-capacity, eco- efficiency, eco-effectiveness and eco-collaboration (Butler, 2011). Whereas Brooks et al. (2012) sees Green IS as an incentive of using IT infrastructure to change organizational processes and/or practices in order to improve energy efficiency and decrease the level of environmental impact, while introduce environmental friendly products and services at the same time.

To be even more precise, Green IS represent a wide spectre of solutions, where an information system (a

Table 1: Operationalization of constructs

\begin{tabular}{|c|c|}
\hline & Item \\
\hline GPP & Green IS Adoption - Pollution Prevention \\
\hline GPP1 & Our company encourages the usage of software for reduction of emissions \\
\hline GPP2 & Our company encourages the usage of software for reduction of waste \\
\hline GPP3 & Our company encourages the usage of software for reduction of hazardous and toxic materials \\
\hline GPL & Green IS Adoption - Product Lifecycle \\
\hline GPL1 & $\begin{array}{l}\text { Our company encourages the usage of software for product life cycle management, which enables environmen- } \\
\text { tally friendly sourcing and acquisition }\end{array}$ \\
\hline GPL2 & $\begin{array}{l}\text { Our company encourages the usage of software for product life cycle management, which enables environmen- } \\
\text { tally friendly product/service development }\end{array}$ \\
\hline GPL3 & $\begin{array}{l}\text { Our company encourages the usage of software for product life cycle management, which enables environmen- } \\
\text { tally friendly planning of production/service processes }\end{array}$ \\
\hline GPL4 & $\begin{array}{l}\text { Our company encourages the usage of software for product life cycle management, which enables environmen- } \\
\text { tally friendly distribution and delivery }\end{array}$ \\
\hline GSD & Green IS Adoption - Sustainable Development \\
\hline GSD1 & Our company encourages the usage of software for online collaboration \\
\hline GSD2 & Our company encourages the usage of software for teleworking \\
\hline GSD3 & Our company encourages the usage of software for paperless business processes \\
\hline GSD4 & $\begin{array}{l}\text { Our company encourages the usage of software for measuring and monitoring of organizational environmental } \\
\text { performance }\end{array}$ \\
\hline ICP & Institutional Pressure - Coercive Pressure \\
\hline ICP1 & The regulations are forcing our company to use green IS \\
\hline ICP2 & Suppliers are forcing our company to use green IS \\
\hline ICP3 & Important customers are forcing our company to use green IS \\
\hline IMP & Institutional Pressure - Mimetic Pressure \\
\hline IMP1 & Our company's main competitors, who adopted green IS, have benefited greatly financially \\
\hline IMP2 & Our company's supply chain members, who adopted green IS, are perceived favourably by their customers \\
\hline IMP3 & Our company's supply chain members, who adopted green IS, have benefited greatly financially \\
\hline IEI & Internal Environment Impact \\
\hline IEI1 & The management of our company would like to implement green IS \\
\hline IEI2 & Employees in our company have proposed the implementation of green IS \\
\hline IEI3 & Green IS are a frequent topic of conversation in our company \\
\hline
\end{tabular}


combination of people, software and IT) has an additional functionality that enables a more sustainable performance of business process. Some of often used Green IS are information systems that enable energy consumption management, optimization of production processes, consolidation of data centres and operations, reuse and care for appropriate disposal of IT, micro and macro economical aspects, system performance, efficient usage of a system, as well as social and ethical aspects aligned with purchase. The Green IS research has mainly been focused to energy efficiency (Watson, Boudreau and Chen, 2010) while other forms of Green IS have mainly been neglected in the literature (e.g. information systems for waste reduction management). For example, Energy informatics, a special research field presented by Watson and Boudreau (2011), discusses the importance of IS for the reduction of energy consumption.

According to several academic discussions (Melville, 2010; Watson, Boudreau \& Chen, 2010, vom Brocke, Watson, Dwyer, Elliot \& Melville, 2013), the research and development in the area of Green IS should be encouraged. Zheng (2014) presents organizational, technological and environmental mechanisms as Green IT/IS adoption motivators. Wati and Koo (2012) researched the motivational perspective of Green IS behaviour intention and actual use of Green IS and concluded that several self-determined motivational factors influence the behaviour intention to use Green IS, while there is no significant influence of behaviour intention on actual use. The actual use of Green IS is according to Wati and Koo (2012) influenced by external pressure, not only by motivational factors.

Since all the aspects of sustainability have not been equally researched, and the focus is mainly on environmental aspect of sustainability (Farzad and Junker, 2015), there is a lack of literature on general awareness of social and economic aspect of sustainability related to IS. Therefore, we decided to follow the research on senior managers' attitude to Green IS in Malaysian companies presented by Gholami, Sulaiman, Ramayah and Molla (2013) and divide the concept of Green IS into three basic forms: pollution prevention, product stewardship and sustainable development. Accordingly, the aim of our research was to evaluate the general awareness and the attitude towards Green IS in Slovenian enterprises.

\section{Methods}

A survey was developed based on the previous study presented by Gholami et al. (2013) and Mishra, Akman \& Mishra (2014). Several items were withdrawn based on the issues of translation and importance in regional circumstances, while several items were added based on previous research (Baggia and Brezavšček, 2015).

Items describing the Green IS adoption were obtained from Gholami et al. (2013). Two additional items (Envi- ronmentally friendly product/service development and Planning of production/service processes) were added for the description of Green IS adoption regarding the enterprise's attitude toward the software product lifecycle management, while one item (Measuring and monitoring of organizational environmental performance) was added for the description of enterprise's attitude towards sustainable development. Items discussing the institutional pressure were all adopted from Gholami et al. (2013), while items discussing the internal environment impact were adopted from Mishra, Akman \& Mishra (2014). Items discussed in this paper are presented in Table 1. Five point Likert type scale was used to measure the items.

\subsection{Sampling, data and statistical methods used}

The presented survey was performed as a web survey used to collect data about attitude toward Green IS among managers of Slovenian enterprises. Invitations to the web survey were sent via email to 3623 randomly chosen enterprises in Slovenia, where the sample matched the demographical structure of Slovenian companies according to region and main activity of the enterprise, representing $2 \%$ of all Slovenian enterprises. Companies with less than two employees were excluded from the sample, based on the assumption that their usage of IS in general is limited. In the period from $25^{\text {th }}$ of May 2015 to $25^{\text {th }}$ of August 2015 we received 222 responses in total. The survey was addressed to the director of the enterprise or to the director of the informatics sector.

For the analysis of research questions, different statistical methods were used: one sided independent samples $t$-test, ANOVAs or Robust test of equality of means and multiple linear regression.

\subsection{Characteristics of the enterprises in the sample}

On the question about the main activity of the enterprise (classified according to Statistical Classification of Economic Activities in the European Community, NACE Rev 2, 2008) 185 enterprises provided their response. The largest proportion marked Other Service Activities (13.5\%), Information and Communication (13.0\%), and Manufacturing (10.3\%) (Figure 1). The sample consists of $23 \%$ micro enterprises (up to 9 employees), almost half of the enterprises were small sized (46\%), one quarter of enterprises were medium sized (50 to 249 employees), while $6 \%$ were large enterprises with at least 250 employees.

The questionnaire was fulfilled by $58.2 \%$ of men and $41.8 \%$ of women. The age of the respondents varies from 23 to 65 years, with mean age 43.5 years ( $\mathrm{s}=9.58$ years). 


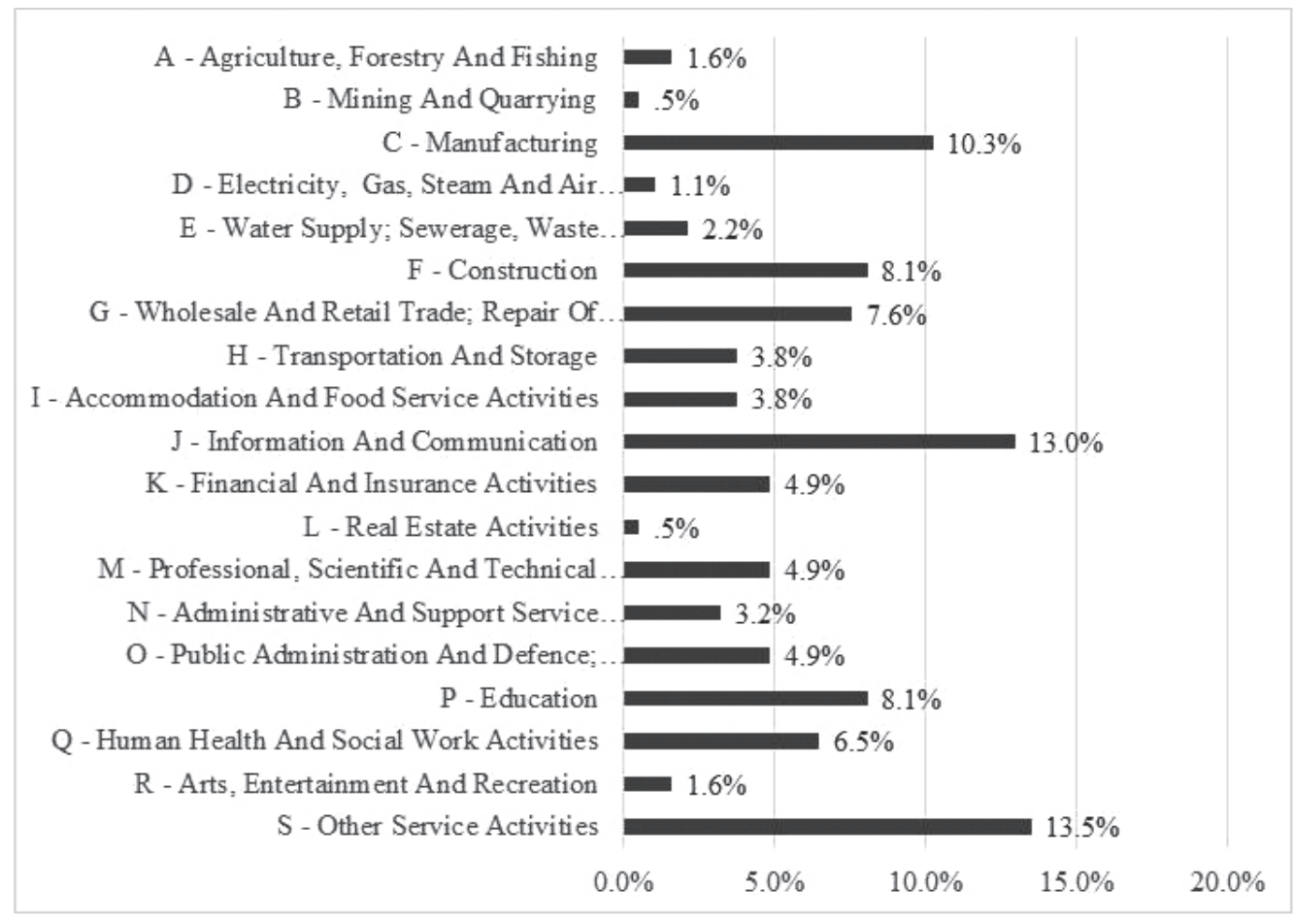

Figure 1: Structure of enterprises in the sample according to their main economic activity

\section{Results}

According to the topic of items in particular subsection, we first discuss the organizational circumstances leading the enterprise to shift their viewpoint to sustainability, second we discuss the promotion of Green IS usage in enterprises. In the last subsection, we discuss the correlations between different circumstances and the promotion for Green IS adoption.

\subsection{Descriptive statistics}

There are several external and internal issues leading the enterprise to shift their viewpoint to a more sustainable and further to use Green IS. Descriptive statistics for measured items and constructs are presented in Table 2. Enterprises receive the highest coercive pressure by regulations (3.16), while suppliers (2.64) and important customers (2.62) have lower impact on usage of Green IS. Among three items of mimetic pressure, the highest average grade received the statement that company's main competitors, who adopted Green IS, have benefited greatly financially (3.04). The highest internal environmental impact on implementation of Green IS have managers (3.19), while the implementation of Green IS is not a frequent topic in the conversations (2.91).
Regarding the adoption of Green IS, all three measured items of Pollution Prevention due to use of software were on average estimated high; 3.89 for software for reduction of waste, 3.87 for software for reduction of hazardous and toxic materials, and 3.80 for software for reduction of emissions. Among four items of Green IS Adoption for Product lifecycle, the companies encourage the most the usage of software that enables planning of production/service processes (3.74) and product/service development (3.73). Encouragement for adoption of Green IS for Sustainable development is the highest for online collaboration (3.96), followed by paperless business processes (3.67), while the least sympathy received measuring and monitoring of organizational environmental performance (2.90) and teleworking (2.93).

In the questionnaire 10 green certificates were listed, and the enterprises marked if they already had it or not and if they are in the process of implementation: ISO 14001 Environmental Management System, ISO 22000 - Food safety management, ISO 26000 - Social responsibility, ISO 50001 - Energy management, EMAS - Eco-Management and Audit Scheme, EcoLabel - label promoting environmental excellence, FSC - Forest Stewardship Council, Family friendly certificate - European work and family audit, SA8000 - Social Accountability International, OHSAS 18001 - Occupational Health and Safety Management 
Table 2: Descriptive statistics of the measured items and constructs

\begin{tabular}{|l|c|c|c|}
\hline Item & $\boldsymbol{N}$ & Mean & SD \\
\hline GPP & 210 & 3.86 & 0.760 \\
\hline GPP1 & 211 & 3.80 & 0.893 \\
\hline GPP2 & 211 & 3.89 & 0.874 \\
\hline GPP3 & 211 & 3.87 & 0.863 \\
\hline GPL & 200 & 3.72 & 0.756 \\
\hline GPL1 & 205 & 3.70 & 0.844 \\
\hline GPL2 & 204 & 3.73 & 0.813 \\
\hline GPL3 & 203 & 3.74 & 0.875 \\
\hline GPL4 & 204 & 3.69 & 0.836 \\
\hline GSD & 202 & 3.37 & 0.771 \\
\hline GSD1 & 203 & 3.96 & 0.872 \\
\hline GSD2 & 205 & 2.93 & 1.165 \\
\hline GSD3 & 205 & 3.67 & 0.942 \\
\hline GSD4 & 204 & 2.90 & 1.036 \\
\hline ICP & 205 & 2.80 & 0.782 \\
\hline ICP1 & 205 & 3.16 & 0.952 \\
\hline ICP2 & 205 & 2.64 & 0.916 \\
\hline ICP3 & 205 & 2.62 & 0.892 \\
\hline IMP & 101 & 2.98 & 0.805 \\
\hline IMP1 & 113 & 3.04 & 0.999 \\
\hline IMP2 & 130 & 2.99 & 0.858 \\
\hline IMP3 & 109 & 2.97 & 0.855 \\
\hline IEI & 196 & 3.04 & 0.816 \\
\hline IEI1 & 197 & 3.19 & 0.869 \\
\hline IEI2 & 198 & 3.01 & 0.934 \\
\hline IEI3 & 198 & 2.91 & 0.965 \\
\hline
\end{tabular}

Systems. Respondents were also allowed to input additional certificates.

There are 136 enterprises that have no sustainability related certificates $(60.7 \%$ out of 224$)$ and 88 enterprises that have from 1 to 10 green certificates, with mean value equal to $2.7(\mathrm{~s}=2.1$ ). More precisely, $20 \%$ of enterprises have ISO 14001 - Environmental management, 6\% have ISO 22000 - Food safety management, $7 \%$ have ISO 26000 - Social responsibility, 8 \% have ISO 50001 - Energy management, 4\% EMAS - Eco-Management and Audit Scheme, 7\% EcoLabel, 11\% have Certificate Family Friendly Enterprise, 5\% have SA 8000 - Social Accountability International, 17\% have OHSAS 18001 - Occupational Health and Safety Management.
The certificates which are in the process of implementation in $9 \%$ of enterprises are ISO 14001 and ISO 50001.

\subsection{Analysis of the research questions}

RQ1: Do the enterprises with at least one implemented sustainability related certificate have on average higher estimates of importance of Green IS adoption than the enterprises who do not have any of sustainability related certificates?

The first research question was analysed with one sided independent samples $t$-tests. Since we assumed that the enterprises with at least one sustainability related certificate will have higher Green IS awareness, one sided $t$-test was performed on all of 11 items expressing the enterprise's attitude towards the implementation of Green IS and other sustainability issues (2-sided $p$-values obtained in SPSS were recalculated as $p / 2$ ). For four out of eleven items the research question was answered positively. Detailed results are presented in Table 3 and Figure 2.

For two out of three items regarding Pollution Prevention due to Green IS Adoption the research question was answered positively. The statement »Our company encourages the usage of software for reduction of emissions." was evaluated statistically significantly higher by enterprises who implemented at least one sustainability related certificate (3.94) than by enterprises where they do not have any of sustainability related certificates (3.73) at $5 \%$ significance level $(t=-1.753, p=.042)$. The statement that company encourages the usage of software for reduction of hazardous and toxic materials was on average evaluated higher by the enterprises with at least one sustainability related certificate (4.06) compared to the other enterprises (3.77) at $5 \%$ significance level $(t=-2.305, p=.011)$. None of four items of Product lifecycle due to Green IS Adoption was evaluated statistically significantly higher by the enterprises with implemented sustainability related certificates, while half of the items in Sustainable development were evaluated statistically significantly higher by the enterprises with implemented sustainability related certificates as assumed. The enterprises with implemented sustainability related certificates encourage paperless business processes (3.85) more than the others (3.58) at 5\% significance level $(t=-1,960, p=.026)$. The same goes for measuring and monitoring the organizational environmental performance, since the average estimate for enterprises with sustainability related certificates is equal to 3.18 and statistically significantly lower (2.75) for the enterprises with no green certificates $(t=-2,886, p=.002)$.

RQ2: Do the enterprises with at least one implemented sustainability related certificate have on average higher estimates of importance of Institutional coercive pressure, Institutional mimetic pressure and Internal environment impact than the enterprises who do not have any of sustainability related certificates? 
Table 3: Descriptive statistics and results of t-test for all 20 items according to enterprises who have implemented sustainability related certificate or not

\begin{tabular}{|c|c|c|c|c|c|c|c|c|c|c|}
\hline \multirow[b]{3}{*}{ Item } & \multicolumn{6}{|c|}{ Number of implemented environmental certificates } & \multirow{2}{*}{\multicolumn{4}{|c|}{$t$-test for equality of means }} \\
\hline & \multicolumn{3}{|c|}{ None } & \multicolumn{3}{|c|}{ At least one } & & & & \\
\hline & $N$ & Mean & SD & $N$ & Mean & SD & $t$ & $d f$ & $p$ (2-sided) & $p$ (1-sided) \\
\hline GPP1 & 139 & 3.73 & .915 & 72 & 3.94 & .837 & -1.735 & 155.5 & .085 & .043 \\
\hline GPP2 & 139 & 3.83 & .884 & 72 & 4.01 & .847 & -1.474 & 209 & .142 & .071 \\
\hline GPP3 & 139 & 3.77 & .854 & 72 & 4.06 & .854 & -2.305 & 209 & .022 & .011 \\
\hline GPL1 & 134 & 3.68 & .855 & 71 & 3.73 & .827 & -.429 & 203 & .668 & .334 \\
\hline GPL2 & 134 & 3.67 & .839 & 70 & 3.84 & .754 & -1.432 & 202 & .154 & .077 \\
\hline GPL3 & 134 & 3.69 & .869 & 69 & 3.84 & .885 & -1.131 & 201 & .259 & .130 \\
\hline GPL4 & 134 & 3.68 & .800 & 70 & 3.70 & .906 & -.169 & 202 & .866 & .433 \\
\hline GSD1 & 131 & 3.90 & .867 & 72 & 4.07 & .877 & -1.321 & 201 & .188 & .094 \\
\hline GSD2 & 133 & 2.87 & 1.202 & 72 & 3.04 & 1.093 & -.994 & 203 & .321 & .161 \\
\hline GSD3 & 133 & 3.58 & .955 & 72 & 3.85 & .899 & -1.960 & 203 & .051 & .026 \\
\hline GSD4 & 132 & 2.75 & .984 & 72 & 3.18 & 1.079 & -2.886 & 202 & .004 & .002 \\
\hline ICP1 & 133 & 3.05 & .976 & 72 & 3.36 & .877 & -2.291 & 203 & .023 & .011 \\
\hline ICP2 & 133 & 2.56 & .941 & 72 & 2.79 & .855 & -1.764 & 203 & .079 & .040 \\
\hline ICP3 & 133 & 2.50 & .858 & 72 & 2.83 & .919 & -2.559 & 203 & .011 & .006 \\
\hline IMP1 & 66 & 3.11 & .963 & 47 & 2.94 & 1.051 & .890 & 111 & .375 & $.812^{\mathrm{a}}$ \\
\hline IMP2 & 79 & 2.92 & .844 & 51 & 3.10 & .878 & -1.130 & 128 & .261 & .130 \\
\hline IMP3 & 68 & 2.90 & .794 & 41 & 3.10 & .944 & -1.189 & 107 & .237 & .119 \\
\hline IEI1 & 125 & 3.07 & .863 & 72 & 3.39 & .848 & -2.497 & 195 & .013 & .007 \\
\hline IEI2 & 126 & 2.90 & .902 & 72 & 3.21 & .963 & -2.281 & 196 & .024 & .012 \\
\hline IEI3 & 126 & 2.78 & .954 & 72 & 3.15 & .944 & -2.670 & 196 & .008 & .004 \\
\hline
\end{tabular}

a One-sided p-value of the item IMP1 was recalculated as 1-p(2-sided)/2, since averages in the sample are just the opposite according to assumption in the second research question.

The second research question was analysed with the one sided independent samples $t$-tests. Since we assumed that the enterprises with at least one sustainability related certificate will have higher estimate of influence from institutional pressure, one sided $t$-test was performed on all of 9 items expressing the enterprise's institutional pressure on sustainability issues (2-sided $p$-values obtained in SPSS were recalculated as $p / 2$ ). For six out of nine items the research question was answered positively. Detailed results are presented in Table 3 and Figure 2.

All three items in Institutional coercive pressure were on average evaluated lower in the enterprises without sustainability related certificate. The enterprises that implemented at least one sustainability related certificate evaluated force of regulations to use Green IS higher (3.36) than the others (3.05) at 5\% significance level $(t=-2.291, p=.011)$. Similarly, the impact of suppliers to use Green IS was on average evaluated higher in the enterprises who already have sustainability related certificates (2.29) than in the enterprises with no sustainability related certificates (2.56) at $5 \%$ significance level $(t=-0.1764, p=.040)$. Higher impact of important customers on use of Green IS is detected by the enterprises who already have sustainability related certificates (2.83) than by the others (2.50) at 5\% significance level $(t=-2.559, p=-.006)$.

None of three items in Institutional Mimetic pressures were evaluated statistically significantly lower by the enterprises with no sustainability related certificate, while the contrary is true for three items of Internal environmental impact. Regarding the Internal Environment Impact, in the enterprises with implemented sustainability related certificates managers have higher desires to implement Green IS (3.39) than in the other enterprises (3.07) at 5\% significance level $(t=-2.281, p=.007)$. Similarly, the initiative of employ- 


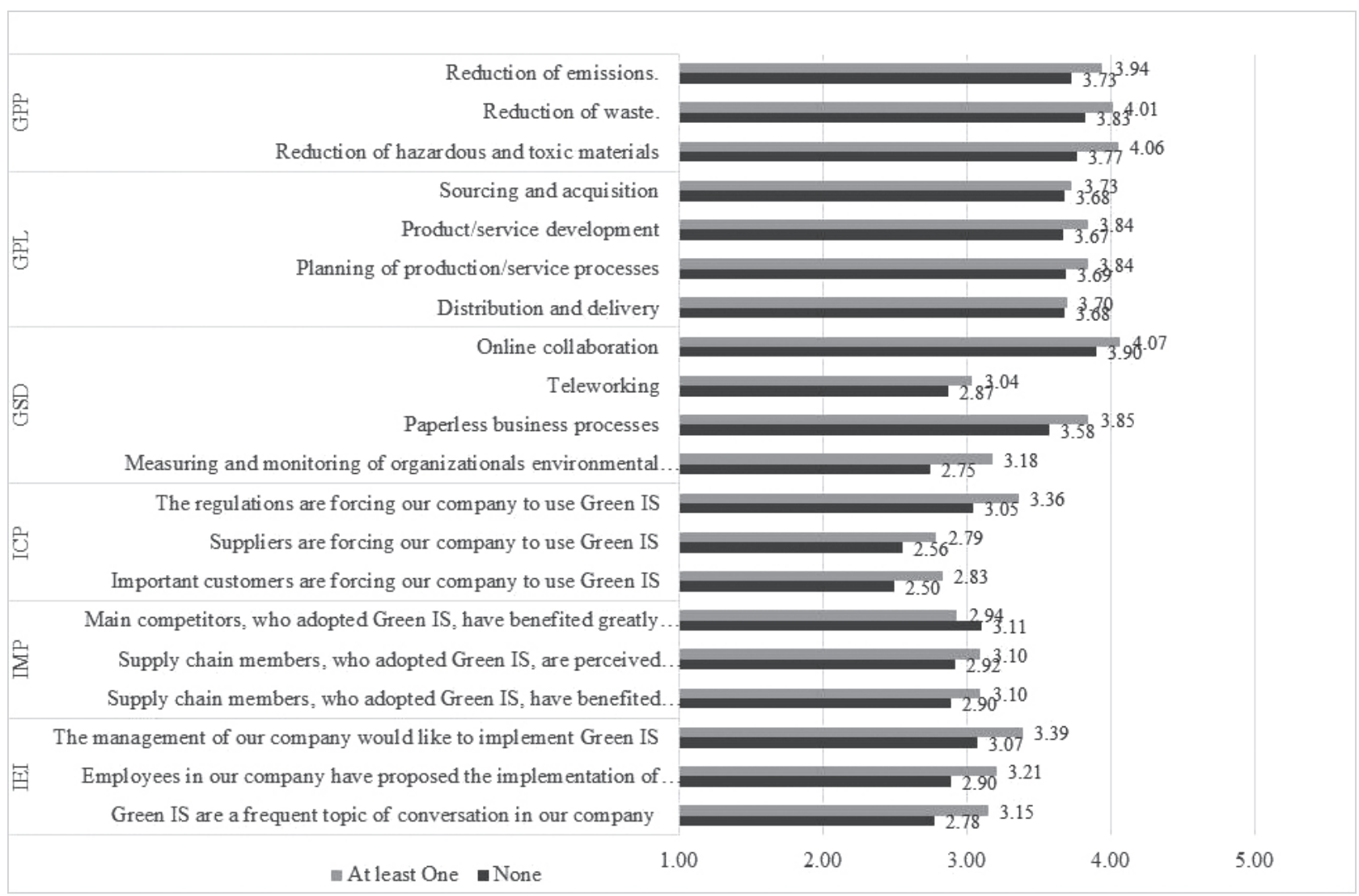

Figure 2: Mean values of 20 items according to enterprises who have implemented sustainability related certificate or not

ees for implementation of Green IS is higher in the employees where they already have any of sustainability related certificates (3.21) than in the others (2.91) at 5\% significance level $(t=-2.281, p=.012)$. In the enterprises where they already have implemented at least one sustainability related certificate Green IS are more frequent topic (3.15) than in the others (2.78) at 5\% significance level $(t=-2.670, p=.008)$.

According to the number of employees, the enterprises are divided into four categories: micro, small, medium, and large. Analyses of variance (ANOVAs) or Robust test of Equality of means in case on unequal variances were used to test whether there exist statistically significant differences in average estimates between enterprises of different sizes of the items. In addition, to investigate groups where the differences exist post hoc tests were used.

RQ3: Are there any differences in the estimates of importance of Green IS adoption among categories according to the size of enterprise?

Statistically significant differences at $5 \%$ significance level were revealed only for one measured item (Table 4 and Figure 3): GSD3 - enterprise encourages use of Green IS for paperless business processes $(F=3.766, p=.012)$.
Games-Howell post hoc test reveals that mean values of GSD3 differentiate significantly among micro (3.47) and large enterprises (4.25) $(p=.003)$ and small (3.63) and large enterprises $(p=.004)$ at $5 \%$ significance level.

RQ4: Are there any differences in the estimates of importance of Institutional coercive pressure, Institutional mimetic pressure and Internal environment impact among categories according to the size of enterprise?

Statistically significant differences at $5 \%$ significance level were revealed only for two measured items (Table 4 and Figure 3): ICP1 - the regulations are forcing the enterprise to use green IS; $(F=4.032, p=.09)$ and IEI2 - employees in our company have proposed the implementation of Green IS ( $F=2.747, p=.044)$. Games-Howell post hoc test reveals that mean values of ICP1 show statistically significant differences only between small (2.99) and large enterprises (3.83) at 5\% significance level $(p=.024)$. Gabriel post hoc test reveals that for IEI2 significant differences in average estimates exist between small (2.89) and large (3.19) enterprises at 5\% significance level ( $p=.046)$.

${ }^{R}$ Robust test (more precisely, Brown-Forsythe test) in the case of unequal variances among groups. 
Table 4: Descriptive statistics and results of ANOVAs for 20 items according to the size of enterprises

\begin{tabular}{|c|c|c|c|c|c|c|c|c|c|c|c|c|c|c|}
\hline \multirow[b]{3}{*}{ Item } & \multicolumn{12}{|c|}{ Number of employees } & \multirow{2}{*}{\multicolumn{2}{|c|}{$\begin{array}{c}\text { ANOVA / } \\
\text { RRobust test }\end{array}$}} \\
\hline & \multicolumn{3}{|c|}{$1-9$} & \multicolumn{3}{|c|}{$10-49$} & \multicolumn{3}{|c|}{$50-249$} & \multicolumn{3}{|c|}{ More than 500} & & \\
\hline & $N$ & Mean & SD & $N$ & Mean & SD & $N$ & Mean & SD & $N$ & Mean & SD & $F$ & $p$ \\
\hline GPP1 & 45 & 3.82 & .984 & 88 & 3.72 & .909 & 48 & 3.83 & .859 & 12 & 4.08 & .900 & .658 & .579 \\
\hline GPP2 & 45 & 4.00 & .905 & 88 & 3.83 & .874 & 48 & 3.92 & .846 & 12 & 4.08 & .900 & .562 & .640 \\
\hline GPP3 & 45 & 3.84 & .999 & 88 & 3.84 & .786 & 48 & 3.88 & .914 & 12 & 4.00 & .953 & .124 & .946 \\
\hline GPL1 & 44 & 3.77 & .912 & 87 & 3.56 & .872 & 48 & 3.85 & .772 & 12 & 3.67 & .651 & 1.398 & .245 \\
\hline GPL2 & 43 & 3.65 & .948 & 87 & 3.71 & .761 & 48 & 3.85 & .799 & 12 & 3.92 & .669 & .706 & .550 \\
\hline GPL3 & 44 & 3.59 & .996 & 86 & 3.76 & .825 & 48 & 3.90 & .905 & 11 & 3.82 & .603 & .943 & .421 \\
\hline GPL4 & 44 & 3.64 & .892 & 86 & 3.71 & .795 & 48 & 3.69 & .926 & 12 & 3.67 & .651 & .074 & .974 \\
\hline GSD1 & 45 & 3.93 & .751 & 87 & 3.87 & .950 & 48 & 4.06 & .885 & 12 & 4.42 & .515 & 1.620 & .186 \\
\hline GSD2 & 45 & 2.96 & 1.127 & 88 & 2.84 & 1.202 & 48 & 3.02 & 1.158 & 12 & 3.58 & .900 & 1.513 & .213 \\
\hline GSD3 & 45 & 3.47 & 1.079 & 88 & 3.63 & .963 & 48 & 3.85 & .772 & 12 & 4.25 & .452 & 3.766 & $.012^{\mathrm{R}}$ \\
\hline GSD4 & 45 & 2.87 & 1.140 & 87 & 2.84 & .987 & 48 & 2.94 & .998 & 12 & 3.50 & 1.000 & 1.493 & .218 \\
\hline ICP1 & 45 & 3.11 & .910 & 88 & 2.99 & .851 & 48 & 3.38 & 1.084 & 12 & 3.83 & .835 & 4.032 & $.009^{\mathrm{R}}$ \\
\hline ICP2 & 45 & 2.62 & .912 & 88 & 2.57 & .868 & 48 & 2.79 & 1.010 & 12 & 2.83 & 1.115 & .765 & .515 \\
\hline ICP3 & 45 & 2.49 & .869 & 88 & 2.63 & .835 & 48 & 2.79 & 1.031 & 12 & 2.67 & .985 & .880 & .452 \\
\hline IMP1 & 26 & 3.12 & .993 & 45 & 2.91 & 1.125 & 29 & 2.97 & .823 & 9 & 3.67 & .707 & 1.556 & .205 \\
\hline IMP2 & 30 & 3.10 & .885 & 55 & 2.93 & .879 & 31 & 2.90 & .831 & 9 & 3.11 & .782 & .412 & .744 \\
\hline IMP3 & 24 & 3.04 & .955 & 43 & 2.91 & .895 & 28 & 2.89 & .786 & 8 & 3.25 & .463 & .490 & .690 \\
\hline IEI1 & 44 & 3.09 & .884 & 88 & 3.11 & .903 & 47 & 3.32 & .810 & 12 & 3.58 & .793 & 1.578 & .196 \\
\hline IEI2 & 45 & 2.93 & .939 & 88 & 2.89 & .915 & 47 & 3.19 & .947 & 12 & 3.58 & .900 & 2.747 & .044 \\
\hline IEI3 & 45 & 2.89 & 1.027 & 87 & 2.84 & 1.010 & 48 & 3.00 & .875 & 12 & 3.17 & .835 & .577 & .631 \\
\hline
\end{tabular}

In the questionnaire, each enterprise has selected one of 19 activities from NACE Rev 2 classification. We reorganized this classification into 7 enterprise categories, as follows:

- Energy: B, D, E

- Industry: $\mathrm{C}, \mathrm{F}$

- Wholesale, retail, hotels \& restaurants: G, I

- Information and communication: J

- Education, science and entertainment: M, P, R

- Public administration, health and social work: O, Q

- Other: A, H, K, L, N, S

RQ5: Are there any differences in estimates of importance of Green IS adoption among seven groups of enterprises according to their main activity?

Among 11 items ANOVAs revealed that only two items from Sustainable development have statistically significant estimates among seven groups of enterprises according to their activity (Table 5, Figure 4). The first one is online collaboration $(F=2.470, p=.027)$, where Games-Howell post hoc test revealed that statistically significant differences exist between Information and communication sector (4.33) and Wholesale, retail, hotels and restaurants (3.48) $(p=.022)$ at $5 \%$ significance level. Second item is teleworking $(F=4.667, p=.000)$, where statistically significant differences at $5 \%$ significance level exist between Information and communication (3.92) and one of the following sectors: Wholesale, retail, hotels and restaurants (2.43) $(p=.000)$, Public administration, health and social work (2.67) ( $p=.004)$ and Other activities (2.71) $(p=.000)$.

RQ6: Are there any differences in estimates of importance of Institutional coercive pressure, Institutional mimetic pressure and Internal environment impact among seven groups of enterprises according to their main activity?

ANOVAs revealed (Table 5), that none of the items from the group of organizational circumstances differ statistically significant. 


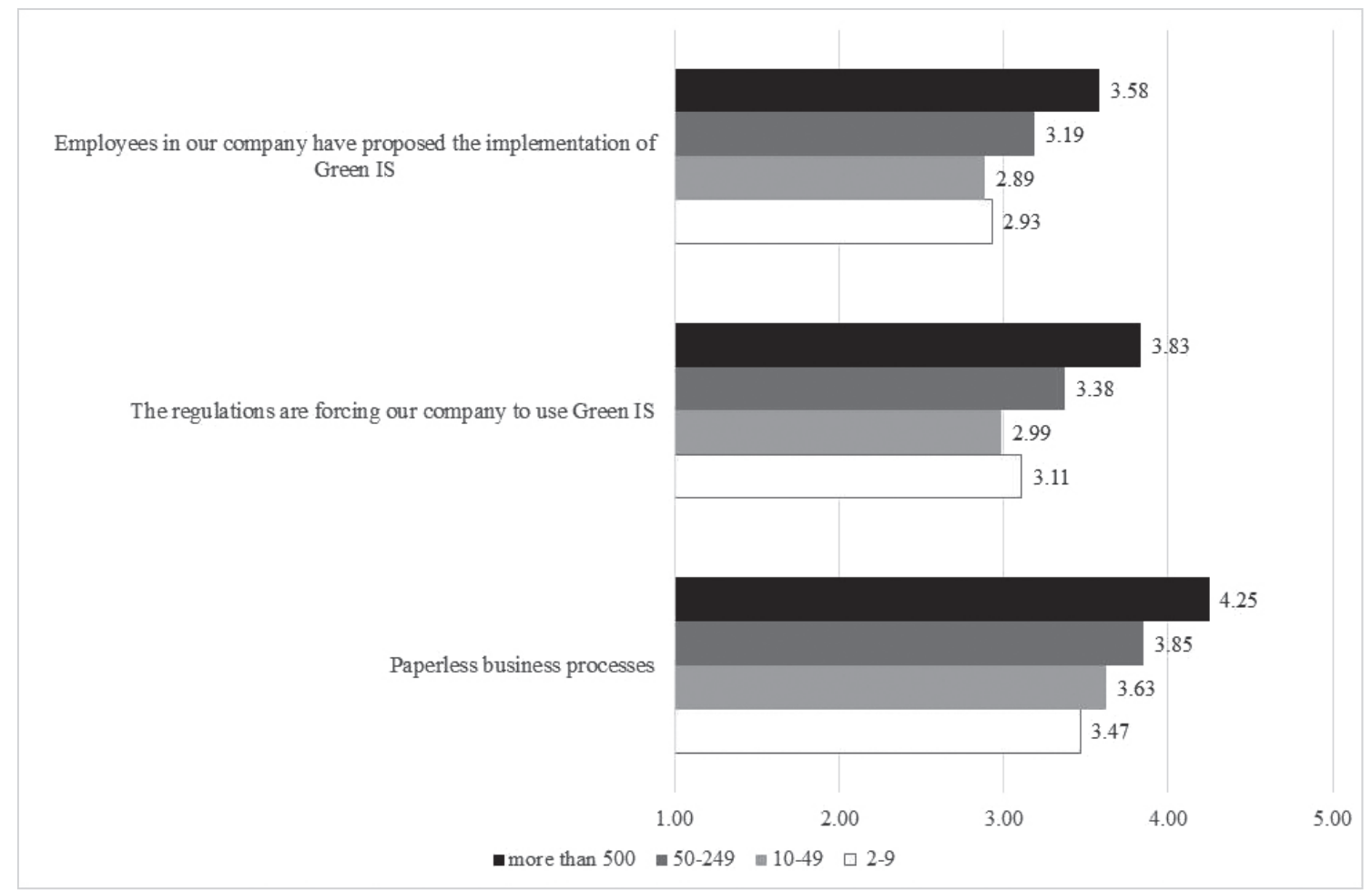

Figure 3: Mean values of three items showing statistically significant differences according to four groups of enterprises according to size

RQ7: What impact have Institutional coercive pressure (ICP), Institutional mimetic pressure (IMP) and Internal environment impact (IEI) on Green IS adoption?

The seventh research question was analysed by multiple linear regression. Three independent variables were calculated as the mean value of measured items in the corresponding construct, while Green IS adoption was calculated as mean value of eleven items included in Pollution Prevention, Sustainable development, and Product lifecycle.

Before examining the regression model itself, correlations among included variables were investigated to rule out the possible problem of multicollinearity. All correlation coefficients among variables are statistically significant at $1 \%$ significance level. More precisely, correlations among dependent variable and predictors are as follows: the highest positive correlation is between IEI and Green IS adoption $(r=0.549)$, followed by correlation coefficient between IMP and Green IS adoption $(r=0.461)$, and correlation between ICP and Green IS adoption $(r=0.412)$. The highest correlation among predictors is between IEI and ICP $(r=0.420)$, followed by correlation between IEI and IMP $(r=0.376)$, and ICM and ICP $(r=0.365)$. Since none of the correlation coefficients is above 0.8 , the multicollinearity is not the problem in our data. Another indicator to rule out the multicollinearity problem are variance inflation factors (VIFs) or the tolerance statistics. The VIFs statistics are for all three predictors in range from 1.227 and 1.493 and therefore relatively close to 1 , while the lowest tolerance statistic for ICP is 0.668 which is highly above 0.2 .

The overall model fit was assessed. $R^{2}$ is equal to 0.41 , indicating that $41 \%$ of variance of the Green IS adoption could be explained with three predictors. Durbin-Watson statistic is 1.368 indicating that errors of the model are independent. Results of ANOVA suggests that the proposed model fits well $(F=21.305, \mathrm{p}=.000)$.

Based on unstandardized regression coefficients, the regression model is as follows:

Green IS adoption $=1.743+0.047 \cdot \mathrm{ICP}+0.226 \cdot \mathrm{IMP}+0.365 \cdot \mathrm{IEI}$

Coefficients for IMP and IE differ statistically significantly from zero ( $p=.003$ and $p=.000$, respectively) at $5 \%$ significance level. Therefore, we can conclude that both Institutional mimetic pressure (IMP) and Internal Environment Impact (IEI) have a positive impact on Green IS adoption.

\section{Conclusions}

According to Melville (2010), information systems are one of the inadequately understood enablers of sustainable business practices. It was therefore not expected that only $15.3 \%$ 


\begin{tabular}{|c|c|c|c|c|c|c|c|c|c|c|c|c|c|c|c|c|c|c|c|c|c|c|}
\hline \multirow{2}{*}{\multicolumn{2}{|c|}{ 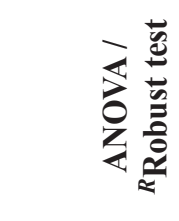 }} & 2 & $\hat{\imath}$ & $\vec{\nabla}$ & $\frac{n}{6}$ & $\begin{array}{l}0 \\
4 \\
n\end{array}$ & . & $\underset{i n}{n}$ & 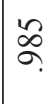 & $\left|\begin{array}{c}\frac{\pi}{\Delta} \\
\delta\end{array}\right|$ & 8 & s̆ & $\begin{array}{l}\infty \\
8 \\
8\end{array}$ & $\widetilde{\widehat{\vartheta}}$ & 守 & $\stackrel{\vec{n}}{\simeq}$ & $\mid \begin{array}{l}\infty \\
0 \\
0 \\
0\end{array}$ & $\frac{ \pm}{\sigma}$ & $\stackrel{\infty}{\stackrel{\infty}{r}}$ & $\cong$ & $\hat{0}$ & بః \\
\hline & & E & $\begin{array}{l}\widetilde{2} \\
\stackrel{\text { ch }}{-}\end{array}$ & ळે & $\underset{I}{ \pm}$ & $\hat{\widehat{\infty}}$ & $\vec{\infty}$ & $\stackrel{\infty}{\curvearrowright}$ & 으. & $\left|\begin{array}{c}\stackrel{P}{f} \\
\dot{v} \\
\text { i }\end{array}\right|$ & $\mid \begin{array}{l}\hat{\overrightarrow{0}} \\
\stackrel{+}{+} \\
\end{array}$ & $\begin{array}{l}\infty \\
\stackrel{+}{\infty} \\
- \\
-\end{array}$ & $\stackrel{n}{\infty}$ & $\stackrel{n}{\stackrel{n}{\sim}}$ & ڤి & $\frac{\varrho}{m}$ & $\hat{\widehat{\sigma}}$ & ণิ) & $\begin{array}{l}0 \\
n \\
n\end{array}$ & $\begin{array}{l}n \\
\hat{\sigma} \\
-1\end{array}$ & 芯 & ○ \\
\hline & \multirow{3}{*}{ ঠே } & के & $\begin{array}{l}\infty \\
\infty\end{array}$ & ळ. & Яุ & ఫ. & $\infty$ & $\hat{\sigma}$ & $\infty$. & $\underset{\infty}{\infty}$. & 을 & ○ِ & $\stackrel{n}{0}$ & $\begin{array}{l}n \\
0 \\
-\end{array}$ & \& & $\widehat{\sigma}$ & $\tilde{\sigma}$ & $\infty$ & ஓे & $\begin{array}{l}\infty \\
\infty \\
\infty\end{array}$ & চ & $\bar{\sigma}$ \\
\hline & & 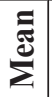 & $\begin{array}{l}\dot{\$} \\
\dot{m}\end{array}$ & $\begin{array}{l}\stackrel{2}{m} \\
\text { m. }\end{array}$ & 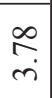 & $\begin{array}{l}\tilde{n} \\
\dot{r}\end{array}$ & 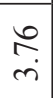 & $\begin{array}{l}\hat{\sigma} \\
\dot{m}\end{array}$ & $\underset{r}{r}$ & $\begin{array}{l}\simeq \\
\dot{\forall}\end{array}$ & $\vec{i}$ & $\begin{array}{l}\vec{b} \\
\dot{m}\end{array}$ & $\begin{array}{l}\dot{\infty} \\
\dot{\sim}\end{array}$ & $\frac{\infty}{\dot{m}}$ & $\vec{i}$ & $\left|\begin{array}{l}\tilde{b} \\
\dot{1}\end{array}\right|$ & 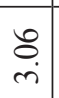 & $\hat{\mathrm{a}}$ & $\hat{\widehat{a}}$ & 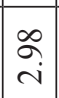 & ঐ. & $\begin{array}{l} \pm \\
\text { i } \\
\text { in }\end{array}$ \\
\hline & & $z$ & $\bar{n}$ & $\bar{n}$ & $\vec{n}$ & $\bar{n}$ & $\bar{n}$ & $\bar{n}$ & $\bar{n}$ & $\bar{n}$ & $\vec{n}$ & $\vec{n}$ & $\vec{n}$ & $\bar{n}$ & $\bar{n}$ & $\bar{n}$ & $\bar{n}$ & $\bar{n}$ & $\bar{n}$ & $\vec{n}$ & $\bar{n}$ & $\bar{n}$ \\
\hline & \multirow{3}{*}{ 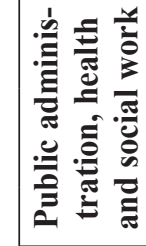 } & ڤి & $\infty$ & $\bar{\sigma}$ & $\stackrel{2}{7}$ & $\infty$ & $\cong$ & $\stackrel{n}{r}$ & $\infty$ & $n$ & 官 & $\sigma$ & ळ. & $\stackrel{\infty}{\infty}$ & $\infty$ & 吉 & $?$ & 8 & $\stackrel{n}{?}$ & $\hat{a}$ & $\stackrel{0}{0}$ & $\vartheta$ \\
\hline & & 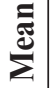 & $\tilde{n}$ & $\begin{array}{l}\hat{\sigma} \\
\dot{m}\end{array}$ & $\begin{array}{l}\infty \\
\infty \\
\dot{r}\end{array}$ & $\begin{array}{l}\hat{\sigma} \\
\dot{r}\end{array}$ & $\begin{array}{l}\hat{\sigma} \\
\dot{m}\end{array}$ & $\begin{array}{l}6 \\
\dot{6} \\
\dot{m}\end{array}$ & $\hat{n}$ & $\left|\begin{array}{l}0 \\
\infty \\
\ddot{r}\end{array}\right|$ & $\mid \begin{array}{l}\hat{\sigma} \\
i \\
i\end{array}$ & $\stackrel{\check{n}}{\tilde{m}}$ & $\begin{array}{l}\stackrel{0}{i} \\
i\end{array}$ & $\begin{array}{c}n \\
\tilde{n}\end{array}$ & $\mid \begin{array}{r}f \\
i\end{array}$ & 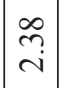 & $\overrightarrow{\widehat{a}}$ & $\begin{array}{l}\infty \\
\dot{i}\end{array}$ & $\stackrel{\infty}{\stackrel{\infty}{r}}$ & $\stackrel{m}{m}$ & ๗ેे & $\underset{8}{8}$ \\
\hline & & z & $\vec{\sim}$ & $\vec{\sim}$ & $\vec{\sim}$ & $\vec{\sim}$ & $\vec{\sim}$ & $\vec{\sim}$ & $\vec{\sim}$ & $\vec{\sim}$ & $\vec{\sim}$ & $\vec{\sim}$ & $\vec{\sim}$ & $\vec{\sim}$ & $\vec{\sim}$ & $\vec{\sim}$ & $\vec{\sim}$ & $\vec{\sim}$ & $\vec{\sim}$ & $\vec{\sim}$ & $\vec{\sim}$ & $\bar{\sim}$ \\
\hline \multirow{9}{*}{ 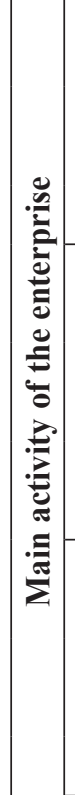 } & \multirow{3}{*}{ 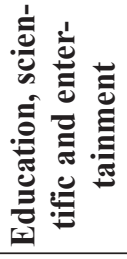 } & बे & $\infty$ & $\infty$ & $\infty$ & $\infty$ & 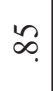 & 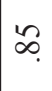 & $\infty$ & $\tilde{\sigma}$ & $\stackrel{\text { İ }}{\text { İ }}$ & $\mathbb{N}$ & ๙ุ & ఫ̦ & $\begin{array}{l}\infty \\
\vdots\end{array} \mid$ & $\hat{a}$ & $\tilde{\sigma}$ & ๙̆ & $\infty$ & ک̆ & $\bar{\sigma}$ & ๑̊ \\
\hline & & $\sum_{\tilde{E}}^{\bar{E}}$ & $\begin{array}{l}\infty \\
\stackrel{\leftrightarrow}{\infty}\end{array}$ & $\begin{array}{l}\dot{O} \\
\dot{\nabla}\end{array}$ & $\begin{array}{l}\underset{+}{+} \\
\dot{\nabla}\end{array}$ & $\begin{array}{l}20 \\
\dot{r}\end{array}$ & $\begin{array}{l}\partial \\
\dot{m}\end{array}$ & $\begin{array}{l}\stackrel{0}{2} \\
\text { ले }\end{array}$ & $\underset{i}{\stackrel{N}{r}}$ & $\left|\begin{array}{l}\partial \\
\dot{m}\end{array}\right|$ & $\frac{n}{m}$ & $\begin{array}{l}n \\
\infty \\
\dot{n}\end{array}$ & 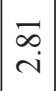 & $\begin{array}{l}\dot{J} \\
\dot{m}\end{array}$ & $\begin{array}{l}n \\
\\
\sim\end{array}$ & $\overrightarrow{\vec{v}}$ & $\begin{array}{l}\vec{J} \\
\text { i }\end{array}$ & $\begin{array}{c}\hat{\infty} \\
i \\
i\end{array}$ & $\stackrel{n}{i}$ & $\stackrel{\hat{n}}{\grave{n}}$ & $\frac{\sim}{m}$ & $\hat{\Omega}$ \\
\hline & & z & 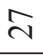 & $\hat{\imath}$ & $\hat{\lambda}$ & $\hat{\imath}$ & $\bar{\lambda}$ & $\bar{\imath}$ & $\widehat{\imath}$ & $\hat{\imath}$ & $\hat{\sim}$ & $\hat{\imath}$ & $\hat{\sim}$ & $\widehat{\imath}$ & $\widehat{\sim}$ & $\hat{\imath}$ & $\hat{\sim}$ & $\hat{\imath}$ & $\widehat{\sim}$ & $\widehat{\imath}$ & $\widehat{\curvearrowright}$ & ヘิ \\
\hline & \multirow{3}{*}{ 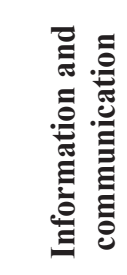 } & हิ & 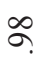 & $\hat{\sigma}$ & $\overrightarrow{\underline{\theta}}$ & $\underline{0}$ & $\curvearrowleft$ & $\stackrel{8}{8}$ & $\underline{\theta}$ & $\infty$ & $\hat{a}$ & $\underset{-}{0}$ & 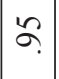 & $\infty$ & : & $\stackrel{g}{a}$ & $\stackrel{2}{2}$ & જ. & $\stackrel{P}{P}$ & $\mid \begin{array}{l}\infty \\
\infty \\
\infty\end{array}$ & ๑ุ & $\stackrel{8}{8}$ \\
\hline & & $\sum_{\Sigma}^{\bar{E}}$ & $\begin{array}{l}\stackrel{0}{+} \\
\dot{m}\end{array}$ & $\begin{array}{l}\tilde{\sigma} \\
\dot{m}\end{array}$ & $\begin{array}{l}\hat{\sigma} \\
\dot{n}\end{array}$ & ले & $\tilde{n}$ & $\vec{\nabla}$ & $\begin{array}{l}6 \\
6 \\
\dot{n}\end{array}$ & $\begin{array}{l}m \\
\tilde{\sigma}\end{array}$ & $\begin{array}{c}\sigma \\
\tilde{r}\end{array} \mid$ & $\begin{array}{l}0 \\
\text { ஸे }\end{array}$ & ڤ̊̀) & ๙ু & $\begin{array}{c}\stackrel{n}{n} \\
\sim\end{array}$ & $\begin{array}{l}\hat{\sigma} \\
\dot{i}\end{array} \mid$ & $\vec{\sim}$ & $\begin{array}{c}\hat{\infty} \\
\stackrel{\sim}{i}\end{array}$ & $\begin{array}{l}\stackrel{2}{i} \\
\text { i }\end{array}$ & $\mid \begin{array}{c}\infty \\
m \\
m\end{array}$ & $\frac{m}{m}$ & $\begin{array}{l}\dot{\Delta} \\
\dot{m}\end{array}$ \\
\hline & & Z & $\stackrel{\Xi}{\sim}$ & $\stackrel{ \pm}{\sim}$ & $\stackrel{\sim}{\sim}$ & $\stackrel{ \pm}{\sim}$ & $\stackrel{ \pm}{\sim}$ & $\stackrel{ \pm}{\sim}$ & $\stackrel{\sim}{\sim}$ & $\stackrel{\sim}{\sim}$ & む & $\stackrel{\sim}{\sim}$ & $\stackrel{\Xi}{\sim}$ & $\stackrel{\searrow}{\sim}$ & $\stackrel{\sim}{\sim}$ & $\stackrel{\Delta}{\sim}$ & $\stackrel{\sim}{\sim}$ & $\stackrel{\sim}{\sim}$ & $\stackrel{\sim}{\sim}$ & $\stackrel{\searrow}{\sim}$ & $\stackrel{\Delta}{\sim}$ & $\stackrel{む}{\sim}$ \\
\hline & \multirow{3}{*}{ 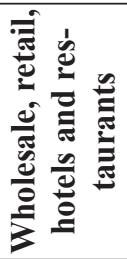 } & हि & ळ. & $\hat{a}$ & ஓे. & $\bar{\infty}$. & $\begin{array}{l}\infty \\
\infty\end{array}$ & $\stackrel{8}{-}$ & S & $\Xi$ & $\begin{array}{l}\infty \\
0 \\
0\end{array}$ & $\stackrel{\infty}{\infty}$ & $\stackrel{\infty}{a}$ & $\mathscr{\infty}$ & $\stackrel{\infty}{\infty}$ & $\stackrel{n}{?}$ & $\stackrel{\sim}{\beth}$ & ส̆ & જ. & $\stackrel{n}{?}$ & $\stackrel{\infty}{\infty}$ & $\infty$ \\
\hline & & 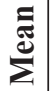 & $\stackrel{\circ}{\stackrel{\circ}{r}}$ & $\hat{n}$ & $\begin{array}{l}\stackrel{0}{+} \\
\dot{\nabla}\end{array}$ & $\mid \begin{array}{l}n \\
\tilde{r} \\
\dot{n}\end{array}$ & $\begin{array}{l}n \\
\dot{n} \\
m\end{array}$ & $\begin{array}{l}n \\
n \\
n\end{array}$ & $\begin{array}{l}8 \\
\dot{0}\end{array}$ & $\begin{array}{l}\infty \\
\dot{+} \\
\dot{\sim}\end{array}$ & $\stackrel{\mathfrak{g}}{\mathrm{i}}$ & $\frac{a}{\dot{m}}$ & $\underset{\stackrel{?}{*}}{\stackrel{\sim}{i}}$ & $\begin{array}{l}\circ \\
\infty \\
i\end{array}$ & $\begin{array}{l}\tilde{n} \\
\sim \\
\sim\end{array} \mid$ & $\mid \begin{array}{l}\infty \\
\stackrel{+}{\sim}\end{array}$ & $\begin{array}{c}8 \\
\dot{r}\end{array}$ & $\begin{array}{l}\hat{\infty} \\
\text { i }\end{array}$ & $\begin{array}{l}\frac{O}{m} \\
\dot{m}\end{array}$ & $\begin{array}{c}\vec{\infty} \\
i\end{array}$ & กี & $\stackrel{\infty}{\sim}$ \\
\hline & & $z$ & $\vec{\sim}$ & $\vec{\sim}$ & $\vec{\sim}$ & $\vec{\sim}$ & $\vec{\sim}$ & $\vec{\sim}$ & $\vec{\sim}$ & $\vec{\sim}$ & $\vec{\sim}$ & $\vec{\sim}$ & $\vec{\sim}$ & $\vec{\sim}$ & $\vec{\sim}$ & $\vec{\sim}$ & $\vec{\sim}$ & $\vec{\sim}$ & $\vec{\sim}$ & $\vec{\sim}$ & $\vec{\sim}$ & $\bar{\sim}$ \\
\hline & \multirow{3}{*}{ 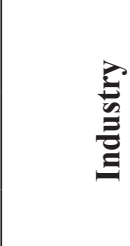 } & के & d & $\bar{\infty}$. & $\begin{array}{l}\infty \\
\infty \\
0\end{array}$ & ळ. & $\nabla$ & 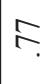 & 索 & $\begin{array}{l}\infty \\
\infty \\
\infty\end{array}$ & $\stackrel{\infty}{\leftrightarrows}$ & 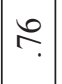 & 9 & $\infty$ & $\bar{a}$ & $\tilde{\infty}$ & $\Xi$ & চ & $\bar{\sigma}$ & $?$ & $\tilde{\sigma}$ & o. \\
\hline & & 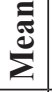 & $\begin{array}{l}\tilde{\gamma} \\
\dot{+}\end{array}$ & $\stackrel{\Delta}{\dot{m}}$ & $\stackrel{2}{r}$ & $\begin{array}{l}\stackrel{2}{2} \\
\stackrel{m}{2}\end{array}$ & $\begin{array}{l}n \\
\infty \\
\dot{m}\end{array}$ & $\begin{array}{l}\infty \\
\infty \\
\dot{m}\end{array}$ & $\begin{array}{l}\overline{6} \\
\dot{r}\end{array}$ & $\begin{array}{c}\hat{\alpha} \\
\dot{m}\end{array}$ & $\begin{array}{c}0 \\
0 \\
\dot{m}\end{array}$ & $\vec{\nabla}$ & 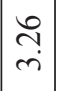 & $\begin{array}{l}\stackrel{0}{0} \\
\stackrel{n}{m}\end{array}$ & $\left|\begin{array}{l}\infty \\
\infty \\
i\end{array}\right|$ & $\left|\begin{array}{c}\widetilde{D} \\
\mathbb{i}\end{array}\right|$ & $\frac{\stackrel{a}{m}}{\dot{m}}$ & $\begin{array}{c}\dot{0} \\
\dot{r}\end{array}$ & $\begin{array}{l}\vec{\infty} \\
i \\
i\end{array}$ & సे. & $\begin{array}{l}g \\
\dot{g}\end{array}$ & $\hat{\tilde{r}}$ \\
\hline & & z & फे & m & $\dot{m}$ & ষ্ঠ & 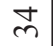 & 志 & 志 & ষ্ট & 志 & 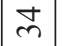 & 吕 & 志 & ষ & 志 & m & mু & m & 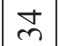 & ল্ & ষ্ল \\
\hline & \multirow{3}{*}{ 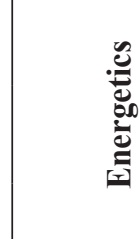 } & के & 2 & oे. & $\stackrel{\infty}{n}$ & $\stackrel{\infty}{\uparrow}$ & $\begin{array}{l}\infty \\
\prod\end{array}$ & F. & 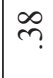 & $\underset{f}{\stackrel{f}{*} .}$ & 官 & $\stackrel{2}{2}$ & g. & बे. & $\begin{array}{l}\infty \\
\cdots \\
\end{array}$ & $\mid \begin{array}{l}\infty \\
?\end{array}$ & $\begin{array}{l}\infty \\
\cdots \\
n\end{array}$ & $\stackrel{n}{n}$ & ำ & $\tilde{n}$ & oे & ळ. \\
\hline & & $\sum^{\bar{E}}$ & in & $\begin{array}{l} \pm \\
\dot{\nabla}\end{array}$ & $\begin{array}{l}8 \\
+ \\
+\end{array}$ & $\begin{array}{l}\triangleright \\
\infty \\
\dot{n}\end{array}$ & $\begin{array}{l}\infty \\
\infty \\
\dot{r}\end{array}$ & $\underset{7}{\stackrel{7}{r}}$ & $\begin{array}{l}\circ \\
\infty \\
\dot{r}\end{array}$ & $\vec{\nabla}$ & $\left|\begin{array}{l}0 \\
0 \\
i\end{array}\right|$ & $\begin{array}{l}\hat{n} \\
n\end{array}$ & స్ & $\underset{\dot{m}}{ \pm}$ & $\begin{array}{l}0 \\
\infty \\
i\end{array} \mid$ & $\begin{array}{l} \pm \\
\dot{m}\end{array}$ & $\begin{array}{l}\stackrel{n}{n} \\
m\end{array}$ & $\stackrel{n}{n}$ & $\stackrel{\sim}{n}$ & 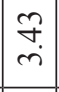 & $\frac{\Delta}{\dot{m}}$ & $\underset{\dot{r}}{8}$ \\
\hline & & z & 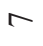 & 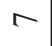 & $r$ & $r$ & $r$ & $r$ & $r$ & - & $r$ & $r$ & $r$ & $r$ & $r$ & $r$ & $r$ & - & $r$ & $r$ & $r$ & $r$ \\
\hline & & & & 章 & $\hat{\tilde{0}}$ & $\overrightarrow{\overrightarrow{0}}$ & 芯 & 荢 & 志 & \begin{tabular}{|l}
$\overrightarrow{0}$ \\
0 \\
0
\end{tabular} \mid & 气ี & $\hat{\hat{2}}$ & 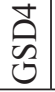 & $\overrightarrow{\tilde{O}}$ & $\tilde{\Theta}$ & $\tilde{\Theta}$ & $\bar{\Xi}$ & $\hat{\Xi}$ & $\sum_{\underline{E}}^{\tilde{E}}$ & $\overrightarrow{\overline{\mid l}}$ & $\stackrel{\mathfrak{I}}{\underline{\theta}}$ & $\stackrel{\theta}{\underline{\Xi}}$ \\
\hline
\end{tabular}




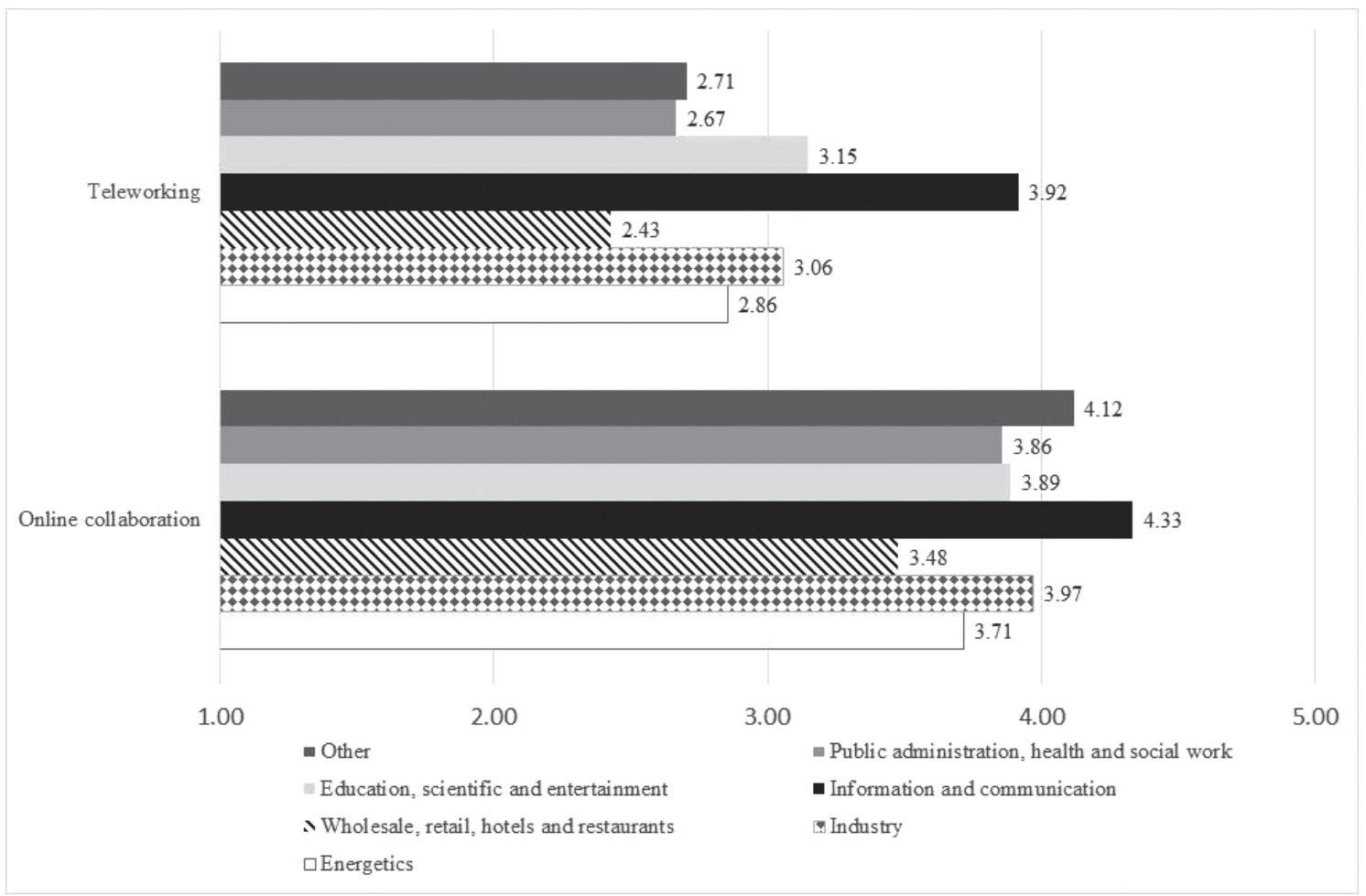

Figure 4: Mean values of two items showing statistically significant differences among seven categories according to enterprise's main activity

of enterprises in the sample do not encourage the use of any Green IS (it was assumed that an enterprise does not encourage the use of any Green IS if the average estimate of Green IS adoption is 3 or less).

Even though, it would be expected that enterprises with sustainability related certificates would promote all listed forms of Green IS, it is evident, that enterprises who already possess at least one of the sustainability related certificates, are more prone only to promote diverse software solutions to lower the GHG emissions, reduce the level of hazardous and toxic materials, paperless business processes and measurements and monitoring of organizational environmental performance. One could also expect that enterprises who measure the organization's environmental performance would put more effort to reduce the environmental impact in the entire life cycle of the product. However, the results show the opposite: the product life cycle is the least used form of Green IS.

Although one could assume, that attitudes and impact on Green IS adoption differ according to the size of the enterprise, only three items showed statistically significant differences:

- the impact of employees on the implementation of Green IS is higher in larger enterprises

- regulations on usage of Green IS have more influence on bigger enterprises
- $\quad$ bigger enterprises are more prone to paperless business process

In general, there are no statistically significant differences among enterprises according to their main activity. Statistically significant difference was found in the adoption of Green IS for sustainable development, where enterprises working in the field of Information and communication had a higher share of online collaboration as wholesale retail, hotels and restaurants as well as a higher share of teleworking as wholesale retail, hotels and restaurants, public administration, health and social work and other activities.

Enterprises who do not feel any pressure from their internal or external environment, do not possess sustainability certificates and do not use Green IS as often as the other enterprises. The results of the survey show that the legislation and suppliers have forced some of the companies to involve sustainability concepts in their business.

It is evident that enterprises who already have implemented the sustainability related certificates, had experienced coercive institutional pressure and internal environment impact in a higher level than the ones without any certificate. The enterprises, who possess sustainability related certificates have a slightly higher attitude towards Green IS adoption. Nevertheless, only $40 \%$ of claims on Green IS adoption is evaluated statistically significantly higher. 
In contrast to Gholami et al. (2013), where results showed that Coercive pressure and Mimetic pressure does not influence the attitude toward Green IS adoption, our results show: Mimetic pressure and Internal Environmental Impact influence the attitude toward Green IS adoption.

Obviously enterprises do not feel the pressure from regulations, suppliers or customers to change their viewpoint to Green IS. Furthermore, the substantial influence was also detected in the case of external environment with Mimetic pressure, which could be aligned with a special national culture of »begrudging the neighbour«, where an enterprise wants to counterpart their competitors or supply chain members in benefits gained from the adoption of Green IS.

In line with Wati and Koo (2012), who found several self-determination factors in influencing Green IS adoption variables, we conclude that the Internal Environmental Impact is the most influential factor of the attitude toward Green IS adoption. The culture or individual perception of managers and employees play an important role in the Green IS adoption.

As with all of the studies, there is a number of limitations and directions for future research. First, as with any study, there is a potential risk of biased results due to subjective interpretations. These potential drawbacks were considered during both the research instrument development phase as well as during the data collection phase. However, we acknowledge that regardless of our efforts, it may not be possible to mitigate this problem. Second, enterprises from one country were addressed. As such, the increase in a sample size could be seen as an opportunity to improve the generalizability and robustness of the research. Third, we acknowledge that there are possible sources of bias concerning the sample distribution. For instance, some smaller enterprises do not have a special IT department and could therefore not be aware of all the possibilities of Green IS and enabling software products. With this limitation in mind, we did exclude the enterprises with only one employee from the sample, but some biased answers are still not excluded. Finally, we recognize that further research is needed to investigate the aspects of Green IS to determine at what level it is institutionalized and why differences occur in deploying sustainability practices related to IS.

Our further investigation of the readiness to adopt Green IS, and the use of information systems as an enabler of sustainable development, will be focused at individual's characteristics and perception impact on the Green IS adoption in enterprises.

\section{Literature}

Baggia, A. \& Brezavšček, A. (2015). Green information systems. In Doucek P., Novak A. \& Paape B. (Eds.). Internationalization and cooperation: Proceedings of the 34th International Conference on Organizational Science Development. Kranj: Moderna organizacija, 66-76.
Boudreau, M. -C., Chen, A., \& Huber, M. (2007). Green IS: Building Sustainable Business Practices. Information Systems, Global Text Project,1-15.

Brooks, S., Wang, X., \& Sarker, S. (2012). Unpacking Green IS: A Review of the Existing Literature and Directions for the Future. In J. vom Brocke, S. Siedel \& J. Recker (Eds.), Green Business Process Management. (15-37). Berlin: SpringerVerlag.

Butler, T. (2011). Towards a Practice-Oriented Green IS Framework. Proceedings of European Conference on Information Systems. Helsinki: ECIS.

Dedrick, Jason (2010). Green IS: Concepts and Issues for Information Systems Research, Communications of the Association for Information Systems, 27, Article 11.

Esfahani, M. D., Rahman, A. A. in Zakaria, N.H. (2015). The Status Quo and the Prospect of Green IT and Green IS: A Systematic Literature Review. Journal of Soft Computing and Decision Support Systems, 2(1), 18-34.

Farzad, T. \& Junker, H. (2015). Towards Sustainability Information Systems. Procedia Computer Science, 64, 1130-1139, http:// dx.doi.org/10.1016/j.procs.2015.08.587

Gholami, R., Sulaiman, A. B., Ramayah, T. in Molla, A. (2013). Senior managers' perception on green information systems (IS) adoption and environmental performance: Results from a field survey, Information \& Management, 50(7), 431-438, http://dx.doi.org/10.1016/j.im.2013.01.004

McKinsey Global Institute (2008). The Carbon Productivity Challenge: Curbing Climate Change and Sustaining Economic Growth, McKinsey \& Company.

Melville, N. P. (2010). Information Systems Innovation for Environmental Sustainability. MIS Quaterly. 34(1), 1-21.

Mishra, D., Akman, I. \& Mishra, A. (2014). Theory of Reasoned Action application for Green Information Technology acceptance. Computers in Human Behavior, 36, 29-40, http://dx.doi. org/10.1016/j.chb.2014.03.030

Seidel, S., Recker, J. C., Pimmer, C., vom Brocke, J. (2010). Enablers and barriers to the organizational adoption of sustainable business practices. In Leidner D. \& Elam J. (Eds). Proceedings of the 16th Americas Conference on Information Systems: Sustainable IT Collaboration around the Globe, Association for Information Systems, Lima.

Siedel, S., vom Brocke, J., \& Recker, J. (2011). Call for Action: Investigating the Role of Business Process Management in Green IS. Proceedings of SIGGreen Workshop. Sprouts: Working Papers on Information Systems.

vom Brocke, J., Watson, R., Dwyer, C., Elliot, S., \& Melville, N. (2013). Green Information Systems: Directives for the IS Discipline. Communications of the Association for Information Systems (CAIS), 33(30), 509-520.

Wati, Y. \& Koo, C. (2012). Toward Green IS Adoption Behaviors: A Self-Determination Perspective. $45^{\text {th }}$ Hawaii International Conference on System Sciences, Maui: IEEE, 1207 - 1216.

Watson, R. \& Boudreau, M. -C. (2011). Energy Informatics. Green ePress. Kindle Edition.

Watson, R., Boudreau, M. -C., \& Chen, A. (2010). Information Systems and Environmentally Sustainable Development: Energy Informatics and New Directions for the IS Community. MIS Quarterly. 34 (1), 23-28.

Watson, R. T., Boudreau, M. C., Chen, A., and Huber, M. H. 2008, Green IS: Building Sustainable Business Practices, in 
Information Systems, R. T. Watson (Ed.), Athens, GA: Global Text Project.

WWF/Gartner (2008). »Assessment of Global Low-Carbon and Environmental Leadership in the ICT Sector«, Stamford, CT: Gartner.

Zheng, D. (2014). The adoption of green information technology and information systems: An evidence from corporate social responsibility. Pacific Asia Conference on Information Systems (PACIS) Proceedings, Paper 237. Retrieved from http://aisel.aisnet.org/pacis2014/237.

Alenka Baggia is an Assistant Professor of Quality and Information Systems at the Faculty of Organizational Sciences University of Maribor. Her main research interests are resource scheduling, simulation and information system sustainability.

Alenka Brezavšček is an Assistant Professor of Stochastic Processes at the Faculty of Organizational Sciences, University of Maribor. Her main research interests are stochastic processes, system reliability and availability, and information system security.

Matjaž Maletič is an Assistant Professor at the Faculty of Organizational Sciences, University of Maribor. His main research interests focus on understanding the phenomenon of organizational ambidexterity, especially from the perspective of the exploitation-exploration paradigm, corporate sustainability, quality management, and organizational performance. He obtained his PhD degree in Quality Management from the University of Maribor, Faculty of Organizational Sciences.

Petra Šparl is an Associate Professor of Mathematics at the Faculty of Organizational Sciences, University of Maribor, Slovenia. Her main research interests are graph theory, data analysis and students' performance in methodological courses.

Hendry Raharjo obtained his Joint-PhD degree from National University of Singapore and Eindhoven University of Technology. He is working as an Assistant Professor at the Division of Quality Sciences and the Centre for Healthcare Improvement $(\mathrm{CHI})$ at Chalmers University of Technology. His research focuses on the use of quantitative methods and statistical engineering in product and service quality improvement works.

Anja Žnidaršč is an Assistant Professor of Quantitative Methods at the Faculty of Organizational Sciences, University of Maribor, Slovenia. Her main research interests are social network analysis, micro-enterprises and information-communication technology, and students' performance in methodological courses. 